\title{
Content and fluorescence of chlorophyll in eucalypt exposed to glyphosate
}

\section{Leonardo Bianco de Carvalho ${ }^{1 *}$, Pedro Luis da Costa Aguiar Alves ${ }^{2}$, and Thiago Cavalcante Gomes Ribeiro de Andrade ${ }^{1,3}$}

\footnotetext{
${ }^{1}$ Santa Catarina State University, Lages, SC, Brazil.

${ }^{2}$ São Paulo State University, Jaboticabal, SP, Brazil.

${ }^{3}$ Federal University of Pará, Altamira, PA, Brazil.
}

\begin{abstract}
The objective was to evaluate the response of eucalypt clonal (Eucalyptus urograndis) regarding on chlorophyll content and fluorescence of chlorophyll after glyphosate spraying to verify if the herbicide affects the photochemical process of photosynthesis. Plants of four eucalypt clonal (C219, GG100, 1144, and 1224), having four expanded leaves, were sprayed with glyphosate in range of doses varying from 0 up to $720 \mathrm{~g} \mathrm{ae} \mathrm{ha}^{-1}$. We evaluated the chlorophyll content and the relation Fv/Fm during 30 days after spraying glyphosate. The chlorophyll content of the clone C219 reduced by $12 \%$ at doses $\geq 360 \mathrm{~g}$ ae ha ${ }^{-1}$. In addition, chlorophyll content was higher $(\geq 12 \%)$ in al clonal from 7 days after spraying. The relation $\mathrm{Fv} / \mathrm{Fm}$ did not alter after glyphosate spraying. We concluded that the efficiency of the photosystem II is not influenced by glyphosate in any studied eucalypt clonal, although doses of glyphosate from $360 \mathrm{~g}^{2}$ ae ha ${ }^{-1}$ affect the chlorophyll content of the clonal C219.
\end{abstract}

Keywords: Eucalyptus urograndis, $N$-(phosphonomethyl)glycine, Dose-response. 


\section{INTRODUCTION}

Weed management in perennial crops, including eucalypt (Eucalyptus spp.), is commonly performed by association of inter-row mechanical control and intrarow chemical control (Carvalho et al. 2013), causing a risk for herbicide drift on the crop of interest and, as a consequence, risk to damage the crop growth development, and production. In this system of weed management, glyphosate is the main herbicide used. Being a non-selective herbicide, glyphosate drift can cause reduction of plant growth or even plant death if lethal doses reach the crop of interest.

Cedergreen and Olesen (2010) and Carvalho et al. (2012) observed glyphosate affecting indirectly the photosynthesis, regarding on gas exchange processes, but not elucidated the mechanisms by which glyphosate can influence on photosynthesis. Huang et al. (2012) studied some factors of light processes of photosynthesis affected by glyphosate exposure, but some doubts are reveled.

The objective of this research is to evaluate the response of eucalypt clonal (Eucalyptus urograndis) regarding on chlorophyll content and fluorescence of chlorophyll after glyphosate spraying to verify if the herbicide affects the photochemical process of photosynthesis.

\section{MATERIAL AND METHODS}

Young plants of eucalypt (Eucalyptus urograndis), clonal C219, GG100, I144, and I224 (Fibria, Brazil) grew in 3-L pots containing sand+organic substrate in a proportion of $2: 1 \quad(\mathrm{v} / \mathrm{v})$ and were submitted to glyphosate (isopropylamine salt, $360 \mathrm{~g}$ ae $\mathrm{L}^{-1}$ ) spraying In a range of doses of $0,18,36,72,180,360$, and $720 \mathrm{~g}$ ae ha $^{-1}$. Herbicide was sprayed using a $\mathrm{CO}_{2}$-pressurized sprayer with flat plan nozzles (TeeJet, 80.02 , USA), pressure of $1.90 \mathrm{kgf} \mathrm{cm}^{-2}$, and volume of application of $200 \mathrm{~L} \mathrm{ha}^{-1}$. Experiment was performed in a completely randomized design with six replicates.

Plants were maintained in a growth chamber at $25 \pm 2{ }^{\circ} \mathrm{C}$ temperature, $80 \pm 5 \%$ air humidity, and $14 \mathrm{~h}: 10 \mathrm{~h}$ (light:dark) photoperiod, during 30 days after glyphosate spraying. Daily irrigation was performed using $150 \mathrm{~mL}$ of a nutrient solution (Hoagland and Arnon 1950 ) at $25 \%$ of the original concentration. During this period, we measured the relative content of total chlorophyll (Minolta, SPAD-502, Japan) and variable chlorophyll fluorescence/maximum chlorophyll fluorescence (Fv/Fm) (Hansatech, PEA, England) at $1,2,3,4,7,10,15$, and 30 days after glyphosate spraying (DAS).

Data were submitted to analysis of variance (ANOVA) in a $4 \times 7 \times 8$ (4 clonal, 7 glyphosate doses, and 8 periods of evaluation) factorial scheme, and means were compared by Tukey HSD, at $5 \%$ of probability, by using Statistica ${ }^{\circledR}$ (StatSoft, version 8.0, USA).

\section{RESULTS AND DISCUSSION}

ANOVA on relative content of chlorophyll indicated interaction between clonal and glyphosate doses $(P<0.001)$, in addition to the isolated factors clonal and doses (Table 1). In general, chlorophyll content was dependent on glyphosate dose just for C219, being mainly reduced at doses 360 and $720 \mathrm{~g}$ ae ha ${ }^{-1}$ (Table 2). In addition, C219 showed generally higher total chlorophyll content (52.3 and 51.4 RU) than the other clonal (46.3 and $47.4 \mathrm{RU}$ ) at doses 0 and $18 \mathrm{~g}_{\text {ae }} \mathrm{ha}^{-1}$, not observed for other doses. Chlorophyll content was generally dependent on the time of evaluation, so that from 7 DAS chlorophyll content was similar (50.0 and 51.2 RU) and higher than those ones observed at 1 and 4 DAS (43.9 and $47.0 \mathrm{RU})$ (Table 3). These results indicate that chlorophyll content is not dependent on the plant exposure to glyphosate, being a specific characteristic of the plant growth stage.

ANOVA indicated no interaction and no effect of isolated factors $(P>0.05)$ (Table 4). The eucalypt clonal C219, GG100, I144, and I224 showed similar $\mathrm{Fv} / \mathrm{Fm}$, varying from 0.809 up to 0.813 for the factor clonal, from 0.803 up to 0.814 for the factor glyphosate dose, and from 0.804 up to 0.814 for the factor time of evaluation (Table 5). These results indicate that the quantum efficiency of the photosystem II is not influenced by glyphosate exposure for the studied clonal, even C219 showing reduction of the chlorophyll content at high doses of glyphosate.

Glyphosate inhibit the EPSPS enzyme (5-enolpyruvylshikimate-3-phosphate synthase) (EC 2.5.1.19) of the shikimate pathway (Duke et al. 2003). Inhibition of this enzyme results in reductions in shikimate pathway products, such as the aromatic amino acids phenylalanine, tyrosine, and tryptophan that are needed for protein synthesis and products of the these amino acids such as lignin, alkaloids, flavonoids, and benzoic acids necessary for cell wall development, defense against pathogens, and many other processes. Inhibition of EPSPS leads to high levels of shikimate accumulation due in part to unregulated flow of carbon into the shikimate pathway. This drains carbon from other pathways, leading to metabolic dysfunction. Glyphosate preferentially translocates to metabolic sinks, such as meristems and expanding cells, where it slows or stops plant growth. 
Table 1. Analysis of variance on data of relative content of total chlorophyll in eucalypt plants exposed to glyphosate.

\begin{tabular}{|c|c|c|c|c|c|}
\hline $\mathrm{CV}$ & $\mathrm{GL}$ & MS & SS & $\mathrm{F}$ & $P$ \\
\hline Clonal (C) & 3 & 1404 & 468 & 27.669 & $<0.001$ \\
\hline Doses (D) & 6 & 393 & 66 & 3.878 & $<0.001$ \\
\hline Time $(\mathrm{T})$ & 7 & 4106 & 587 & 34.693 & $<0.001$ \\
\hline CxD & 18 & 736 & 41 & 2.418 & $<0.001$ \\
\hline CxT & 21 & 414 & 20 & 1.166 & 0.276 \\
\hline DxT & 42 & 348 & 8 & 0.489 & 0.997 \\
\hline CxDxT & 126 & 899 & 7 & 0.422 & 1.000 \\
\hline Error & 448 & 7,575 & 17 & & \\
\hline Total & 671 & 15,875 & & & \\
\hline
\end{tabular}

Table 2. Relative content of total chlorophyll (interaction between clonal and doses) in eucalypt plants exposed to glyphosate.

\begin{tabular}{cccccc}
\hline \multirow{2}{*}{$\begin{array}{c}\text { Dose } \\
\left(\mathrm{g} \text { ae ha }{ }^{-1}\right)\end{array}$} & \multicolumn{5}{c}{$\begin{array}{c}\text { Chlorophyll } \\
\text { (RU) }\end{array}$} \\
\cline { 2 - 6 } & C219 & GG100 & I144 & I244 \\
\hline 0 & $52.3 \pm 0.7$ a & $47.1 \pm 0.6$ cdef & $47.4 \pm 0.9$ cdef & $46.6 \pm 1.2$ ef \\
18 & $51.4 \pm 0.9$ abc & $46.3 \pm 1.3$ ef & $47.4 \pm 0.5$ cdef & $46.5 \pm 1.0$ ef \\
36 & $52.0 \pm 0.5$ ab & $48.0 \pm 0.8$ abcdef & $47.7 \pm 0.8$ bcdef & $47.8 \pm 1.4$ bcdef \\
72 & $51.2 \pm 1.0$ abc & $48.1 \pm 1.2$ abcdef & $49.1 \pm 0.7$ abcde & $46.5 \pm 0.7$ ef \\
180 & $51.1 \pm 0.9$ abcd & $48.2 \pm 1.3$ abcdef & $46.0 \pm 0.7$ ef & $47.2 \pm 1.1$ cdef \\
360 & $46.6 \pm 0.5$ ef & $44.0 \pm 0.9$ f & $47.8 \pm 0.9$ bcdef & $47.7 \pm 1.2$ bcdef \\
720 & $48.6 \pm 1.0$ abcde & $46.2 \pm 0.8$ ef & $46.7 \pm 1.1$ def & $47.6 \pm 0.7$ bcdef \\
\hline
\end{tabular}

Obs. Means \pm standard error of six replicates followed by the same letter do not differ by the Tukey HSD test at $5 \%$ of probability.

Table 3. Relative content of total chlorophyll (isolated factor for time of evaluation) in eucalypt plants exposed to glyphosate.

\begin{tabular}{ccl}
\hline $\begin{array}{c}\text { Time } \\
\text { (days) }\end{array}$ & $\begin{array}{c}\text { Chlorophyll } \\
\text { (RU) }\end{array}$ & \\
\hline 1 & $43.9 \pm 0.6$ & $\mathrm{~d}$ \\
2 & $45.6 \pm 0.5$ & cd \\
3 & $46.9 \pm 0.5$ & bc \\
4 & $47.0 \pm 0.5$ & bc \\
7 & $51.1 \pm 0.5$ & a \\
10 & $51.2 \pm 0.5$ & a \\
15 & $50.0 \pm 0.4$ & a \\
30 & $50.1 \pm 0.3$ & a \\
\hline
\end{tabular}

Obs. Means \pm standard error of six replicates followed by the same letter do not differ by the Tukey HSD test at $5 \%$ of probability.

Table 4. Analysis of variance on data of variable fluorescence/maximum fluorescence of chlorophyll in eucalypt plants exposed to glyphosate.

\begin{tabular}{cccccc}
\hline CV & GL & MS & SS & F & P \\
\hline Clonal (C) & 3 & 0.0104 & 0.0035 & 3.278 & 0.051 \\
Doses (D) & 6 & 0.0140 & 0.0023 & 2.204 & 0.062 \\
Time (T) & 7 & 0.0121 & 0.0017 & 1.634 & 0.124 \\
CxD & 18 & 0.0222 & 0.0012 & 0.168 & 0.284 \\
CxT & 21 & 0.0152 & 0.0007 & 1.002 & 0.847 \\
DxT & 42 & 0.0444 & 0.0011 & 0.860 & 0.471 \\
CxDxT & 126 & 0.1143 & 0.0009 & 0.0011 & 0.845 \\
\hline Error & 448 & 0.4728 & & &
\end{tabular}


Table 5. Variable fluorescence/maximum fluorescence of chlorophyll (Fv/Fm) in eucalypt plants exposed to glyphosate.

\begin{tabular}{cc}
\hline Clonal & Fv/Fm \\
\hline C219 & $0.809 \pm 0.008$ \\
GG100 & $0.810 \pm 0.006$ \\
I144 & $0.813 \pm 0.007$ \\
I224 & $0.811 \pm 0.009$ \\
\hline Doses $\left(\mathrm{g}\right.$ ae ha $\left.{ }^{-1}\right)$ & $0.810 \pm 0.004$ \\
\hline 0 & $0.812 \pm 0.007$ \\
18 & $0.807 \pm 0.008$ \\
36 & $0.814 \pm 0.005$ \\
72 & $0.810 \pm 0.004$ \\
180 & $0.810 \pm 0.007$ \\
360 & $0.803 \pm 0.006$ \\
720 & \\
\hline Time (days) & $0.814 \pm 0.008$ \\
\hline 1 & $0.810 \pm 0.010$ \\
3 & $0.809 \pm 0.009$ \\
4 & $0.808 \pm 0.009$ \\
7 & $0.807 \pm 0.009$ \\
10 & $0.806 \pm 0.008$ \\
15 & $0.814 \pm 0.007$ \\
30 & $0.804 \pm 0.009$ \\
\hline & \\
\hline &
\end{tabular}

There are many indirect effects of glyphosate, such as decreased levels of the activity of the enzyme ribulose1,5-biphosphate carboxylase/oxygenase (Rubisco) (Ahsan et al. 2008) and disorganization of the photosynthetic apparatus (María et al. 2005). Other general consequences of the exposure to glyphosate are chlorosis and plant growth reduction, mainly in metabolically active tissues, such as immature leaves, sprouts, floral buds, and root tips. At high glyphosate doses, these symptoms are followed by plant death.

Huang et al. (2012) observed that the content of both chlorophyll $a$ and $b$ in leaves markedly decreased, according the concentration and time of application of glyphosate. Such changes in the content of both chlorophyll $a$ and $b$ after herbicide application have been demonstrated in several experiments (Pline et al. 1999, Wong 2000, Cakmak et al. 2009, MateosNaranjo et al. 2009, Huang et al. 2012). However, we did not verify that association in our experiment. The decrease of chlorophyll content may be due to an increase of chlorophyll degradation or to a decrease of chlorophyll synthesis (Santos 2004). It was previously reported that herbicide stress induced a reduction in the number of chloroplasts (as discussed by Huang et al. 2012). The glyphosate effect on chlorophyll fluorescence parameters are dependent on concentration and time of application (Huang et al. 2012). However, we did not find any direct evidence of herbicide glyphosate could be influencing the photochemical stage of photosynthesis in eucalypt clonal C219, GG100, I144, and I224 of E. urograndis.

\section{CONCLUSION}

Total content of chlorophyll of the clonal C219 reduces by glyphosate spraying at doses from $360 \mathrm{~g}$ ae ha ${ }^{-1}$, but no effect on quantum efficiency of the photosystem II occurs. Chlorophyll content and efficiency of photosystem II of the clonal GG100, I144, and I244 are not influenced by glyphosate exposure.

\section{Acknowledgements}

Authors thank to FAPESP, CAPES, and CNPq from Brazil.

\section{References}

Ahsan $\mathrm{N}$ et al. 2008. Glyphosateinduced oxidative stress in rice leaves revealed by proteomic approach. Plant Physiology and Biochemistry 46: 1062-1070.

Cakmak I et al. 2009. Glyphosate reduced seed and leaf concentrations of calcium, manganese, magnesium, and iron in non-glyphosate resistant soybean. European Journal of Agronomy 31: 114-119.

Carvalho LB et al. 2012. Physiological dose-response of coffee (Coffea arabica L.) plants to glyphosate depends on growth stage. Chilean Journal of Agricultural Research 72: 182-187.

Carvalho LB et al. 2013. Hormesis with glyphosate depends on coffee growth stage. Anais da Academia Brasileira de Ciências 85: 813-822.

Cedergreen N and Olesen CF. 2010. Can glyphosate stimulate photosynthesis? Pesticide Biochemistry and Physiology 96: 140148.

Duke SO et al. 2003. Herbicides: glyphosate. In: Plimmer JR (Ed.). Encyclopedia of agrochemicals. New York: John Wiley. pp.708869. 
Hoagland DR and Arnon DJ. 1950. The water culture method of growing plants without soil. Berkeley: University of California. 31p.

Huang $\mathrm{J}$ et al. 2012. Effects of glyphosate on photosynthesis, chlorophyll fluorescence and physicochemical properties of cogongrass (Imperata cylindrical L.). Plant Omics Journal 5: 177183.

María $\mathrm{N}$ et al. 2005. Alterations induced by glyphosate on lupin photosynthetic apparatus and nodule ultrastructure and some oxygen diffusion related proteins. Plant Physiology and Biochemistry 43: 985-996.

Mateos-Naranjo E et al. 2009. Effectiveness of glyphosate and imazamox on the control of the invasive cordgrass Spartina densiflora. Ecotoxicology and Environmental Safety 72: 16941700.

Pline WA et al. 1999. Effects of temperature and chemical additives on the response of transgenic herbicide-resistant soybeans to glufosinate and glyphosate applications. Pesticide Biochemistry and Physiology 65: 119-131.

Santos CV. 2004. Regulation of chlorophyll biosynthesis and degradation by salt stress in sunflower leaves. Scientia Horticulturae 103: 93-99.

Wong PK. 2000. Effects of 2,4-D, glyphosate and paraquat on growth, photosynthesis and chlorophyll-a synthesis of Scenedesmus quadricauda Berb 614. Chemosphere 41: 177-182.

\section{RESUMO}

Teor e fluorescência da clorofila em eucalipto exposto a glyphosate. O objetivo com essa pesquisa foi avaliar a resposta de clones de eucalipto (Eucalyptus urograndis) a glyphosate, quanto ao teor de clorofila e à fluorescência de clorofila, para verificar se 0 herbicida afeta a etapa fotoquímica da fotossíntese. Plantas de quatro clones de eucalipto (C219, GG100, I144 e I224), apresentando 4 pares de folhas foram expostas a doses crescentes de glyphosate, variando de 0 a $720 \mathrm{~g}$ e.a. ha ${ }^{-1}$, sendo avaliado o teor de clorofila e a relação $\mathrm{Fv} / \mathrm{Fm}$ durante 30 dias após a aplicação. $\mathrm{O}$ teor de clorofila do clone C219 foi reduzido em até $12 \%$ em doses $\geq 360 \mathrm{~g}$ e.a. ha ${ }^{-1}$. Além disso, o teor de clorofila foi maior $(\geq 12 \%) \mathrm{em}$ todos os clones a partir de 7 dias. A relação $\mathrm{Fv} / \mathrm{Fm}$ não se alterou em função dos tratamentos. Conclui-se que a eficiência do fotossistema II não é influenciada pelo glyphosate em nenhum dos clones estudados, apenar de doses a partir de $360 \mathrm{~g}$ e.a. $\mathrm{ha}^{-1}$ afetarem o teor de clorofila do clone C219.

Palavras-chave: Eucalyptus urograndis., $\mathrm{N}$-(fosfonometil)glicina, Dose-resposta. 